\section{Suicide rates between men and women in Brazil, 2000-2017}

\author{
Taxas de suicídio em homens e mulheres no \\ Brasil, 2000-2017
}

\section{Tasas de suicidio entre hombres y mujeres en Brasil, 2000-2017}

Danielly Cristina de Andrade Palma 1,2 Beatriz Fátima Alves de Oliveira 3

Eliane Ignotti 2

\begin{abstract}
This study aimed to analyze the trend in the standardized suicide rates by gender, according to Brazil's geographic regions from 2000 to 2017. Mortality data were retrieved from the Brazilian Mortality Information System database. Linear regression models were used, and Durbin-Watson tests were applied to detect the independence of the residues, as well as Prais-Winsten to control serial autocorrelation. We classified the trends as increasing, decreasing, and stable at 5\% significance level. The standardized rate of deaths by suicide for men increased by 75\%, from 6.5 to 11.3 deaths per 100,000 inhabitants. For women, the increase was $85 \%$, from 1.6 to 3.0 deaths per 100,000 inhabitants. We found a gradual increase in the standardized suicide rates in all regions for both genders. The growth magnitude of suicide rates in the South is twice for women, whereas for the Northeast it is greater for men. The South and the Central-West regions presented the highest rates, whereas the North the lowest. The trend of standardized rates of suicide is linear and significantly increasing for Brazil and its total geographic regions for both genders. Male and female suicide rates indicate different risk rates according to gender.
\end{abstract}

Mortality; Sex Distribution; Indigenous Peoples

\author{
Correspondence \\ D. C. A. Palma \\ Av. Márcio Lima Nantes s/n, Coxim, MS 79400-000, Brasil. \\ danielly.palma@ufms.br \\ 1 Universidade Federal de Mato Grosso do Sul, Coxim, Brasil. \\ 2 Universidade do Estado de Mato Grosso, Cáceres, Brasil. \\ 3 Escola Nacional de Saúde Pública Sergio Arouca, \\ Fundação Oswaldo Cruz, Rio de Janeiro, Brasil.
}




\section{Introduction}

Suicide is a complex human phenomenon with great effect both individually and collectively, being one of the forms of self-inflicted violence with the highest incidence. According to the World Health Organization (WHO) 1, the overall age-standardized suicide rate was 10.5 deaths per 100,000 inhabitants for 2016 (13.7 men and 7.5 women). In Brazil, suicide is the fourth leading cause of death from external factors, accounting for $8 \%$ of deaths in 20172.

Thus, relevant differences in suicide rates by gender are known as the "gender suicide paradox". One of the most intriguing aspects is why the suicide rates of men are much higher than women. For women, rates are higher for ideation (suicidal thought) and non-fatal suicidal behavior. Females are three times more likely to attempt suicide, whereas men are two to four times more likely to die from a suicide attempt 3,4 .

Men and women tend to adopt self-destructive behaviors with gender particularities 5 . These behaviors include differences in the suicide methods used by each one, which can be differentiated about lethality, availability, and cultural acceptability 6.

Men use more violent and more lethal methods, such as hanging and firearms, whereas for women medicine overdose is more frequent. Once depressed, men are less likely to seek help, therefore alcohol abuse is also more frequent, which makes them impulsive and violent. The male role in society involves more aggressive and competitive behavior. Traditionally, male socialization values these personality aspects that increase the capability for suicide. In many cases, men associate old age with the failure of the traditional role of provider, causing social retraction and depression 5,7,8.

We can associate the lower rate of suicide deaths among women with the lower prevalence of alcoholism, religiosity, greater flexibility in attitudes, the accomplishment of the social roles attributed to them, motherhood, and more chances of seeking help when they feel depressed. However, in cultures where women face inequalities in the social and family environment, they are at a higher risk of committing suicide. Domestic violence and physical abuse also contribute to suicide among women 7,9. In most countries, suicide rates are much higher for men than for women. Nevertheless, some countries, such as Sri Lanka, El Salvador, Cuba, Ecuador, and China, have higher suicide rates among women 6 . The pattern of suicide mortality varies among countries, with considerable disparities in different regions within the same territory. Information on the reason for temporal and spatial variations in suicide rates is still poorly understood 10.

Due to the Brazilian territorial extension, it is relevant to understand the temporal behavior of suicide deaths in different geographic regions, considering the differences between genders. Thus, this study aimed to analyze the trend in standardized suicide rates by gender, according to Brazil's geographic regions from 2000 to 2017.

\section{Method}

This is a trend study of standardized suicide rates by gender, according to the five Brazil's geographic regions from 2000 to 2017. The database of mortality was retrieved from the Brazilian Mortality Information System (SIM), available via the Brazilian Health Informatics Department (DATASUS). According to the 10th International Classification of Diseases (ICD-10), suicide deaths were classified as voluntary self-inflicted injury using codes X60-X84. Since the rate was standardized by age, 433 deaths with missing data were excluded.

Considering the significant number of deaths from external causes reported as undetermined intention (codes: Y10-Y34), the correction of deaths by suicide was conducted through the proportion between deaths by suicide and the total of deaths from external causes for the entire period of studies, and summarized according to the equation 11 :

$$
X s=X+M * X /(T-M)
$$

where: $X s$ is the corrected number of deaths by suicide, $X$ is the number of deaths by suicide, $M$ is the number of deaths due to undetermined intention, and $T$ is the number of deaths due to external causes. 
Suicide rates were standardized by age using the direct method and stratified by gender. The annual rates were calculated for each Brazilian regions, equivalent to groups of 100,000 inhabitants, considering the Brazilian population from the 2010 census (Brazilian Institute of Geography and Statistics - IBGE) as standard.

Secondary sex ratio was used to analyze the inequality of standardized rates by sex. However, the discussion was conducted according to gender.

To verify the temporal variation in the standardized suicide rates, the relative percentage change (RPC) was calculated using the values of the final year of the studied period minus the observed values for the beginning year divided by the observed value for the beginning year multiplied by 10012 .

The trend analysis from 2007 to 2015 was performed using a linear regression model for historical series whose dependent variables were standardized by suicide rates according to sex (Y) and time in years as an independent variable $(\mathrm{X})$. The calendar years were transformed into a year centralized variable (year (X) minus the midpoint of the historical series) in order to avoid self-correlation between the terms of the regression equation. The Durbin-Watson test was used to detect the independence in the residuals, and in the case of serial autocorrelation, the generalized linear regression model of Prais-Winsten 13 was used. The trend was classified as increasing, decreasing, and stable. A 5\% significance level was set, besides the program R version 3.6.1 (http://www.r-project.org) - libraries "lmtest", "prais", and "ggplot2" were used.

This study was approved by the Human Research Ethics Committee of the State University of Mato Grosso (UNEMAT; under opinion n. 2,602,858).

\section{Results}

In the 18 years analyzed (2000-2017), Brazil reported 168,794 suicide deaths. Among these, 133,203 (79\%) were male and 35,566 (21\%) female. The standardized rate increased by 75\%, from 6.5 to 11.3 deaths per 100,000 inhabitants for men. For women, the increase was $85 \%$, from 1.6 to 3.0 deaths per 100,000 inhabitants.

We identified a gradual increase in standardized suicide rates in all Brazilian regions for both sexes, with a constant difference in magnitude between men and women for all regions. The South presents rates much higher than the other Brazilian regions, followed by the Central-West (Figure 1).

The suicide rate in Brazil is four times higher in men than in women. The South region had the highest rates over the analyzed series and the North the lowest. However, we observed the highest RPC in the Northeast (160\% for males and 121\% for females) and North (143\% for males and 154\% for females) (Table 1).

Standardized suicide rates show a linear trend and a significant increase for Brazil and all geographical regions for both sexes, whose models showed a good quality of adjustments. Although the rates are distinct, the slope coefficient shows an identical growth rate between the genders for Brazil, as well for Central-West, North, and Southeast regions. In the South, this coefficient is twice for women, whereas in the Northeast for men (Table 2; Figure 2).

\section{Discussion}

Unlike many countries, Brazil showed a 21\% increase in the suicide rates from 2010 to 2017 . According to $\mathrm{WHO}$, in the same period, the age-standardized rate of suicide deaths decreased globally by 9.8\%, except for the Americas, which increased by $6 \% 1$.

A 2016 study 14 also showed a decrease in age-standardized suicide rates in most regions of the world from 1990 to 2016. Among the 195 countries and territories analyzed, a decline in agestandardized suicide rates was observed in 63 countries. The largest decreases were found in China (64.1\%), Denmark (60\%), Philippines (58.1\%), Singapore (50.6\%) and Switzerland (50.3\%). Excepting Latin America (14.6\%), a high-income region of Asia Pacific (10.1\%), Western Sub-Saharan Africa (4.3\%), and Eastern Europe (1.4\%), which presented ascendant rates. 
Figure 1

Graphs of the evolution of suicide rates in Brazil and geographic regions from 2000 to 2017.

1a) Female

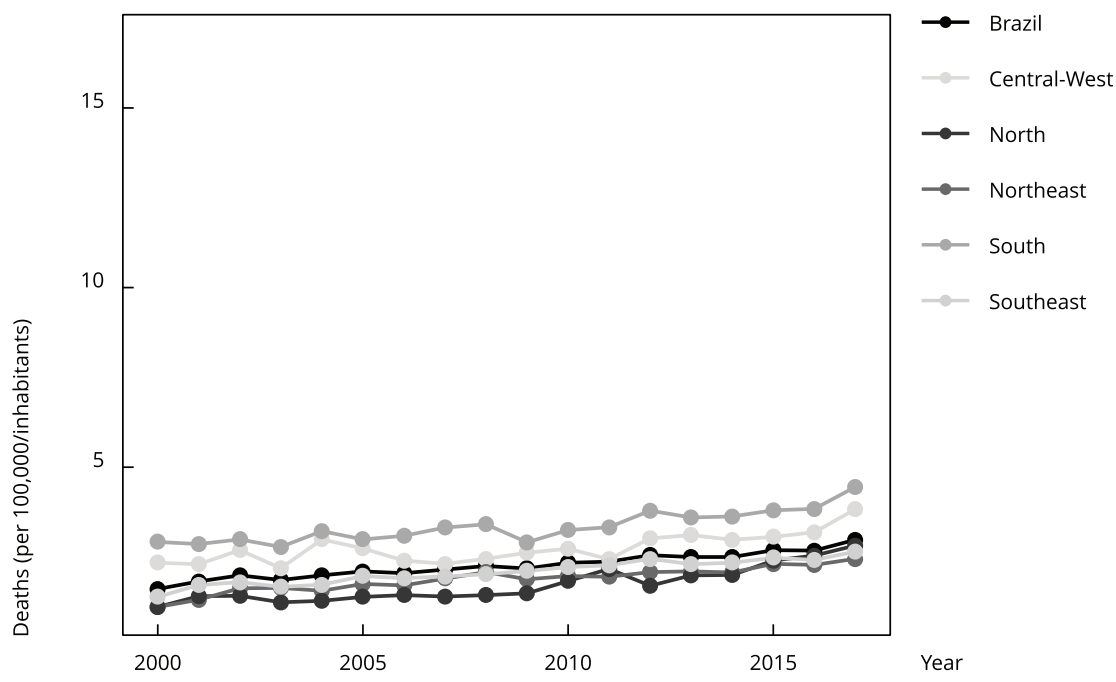

1b) Male

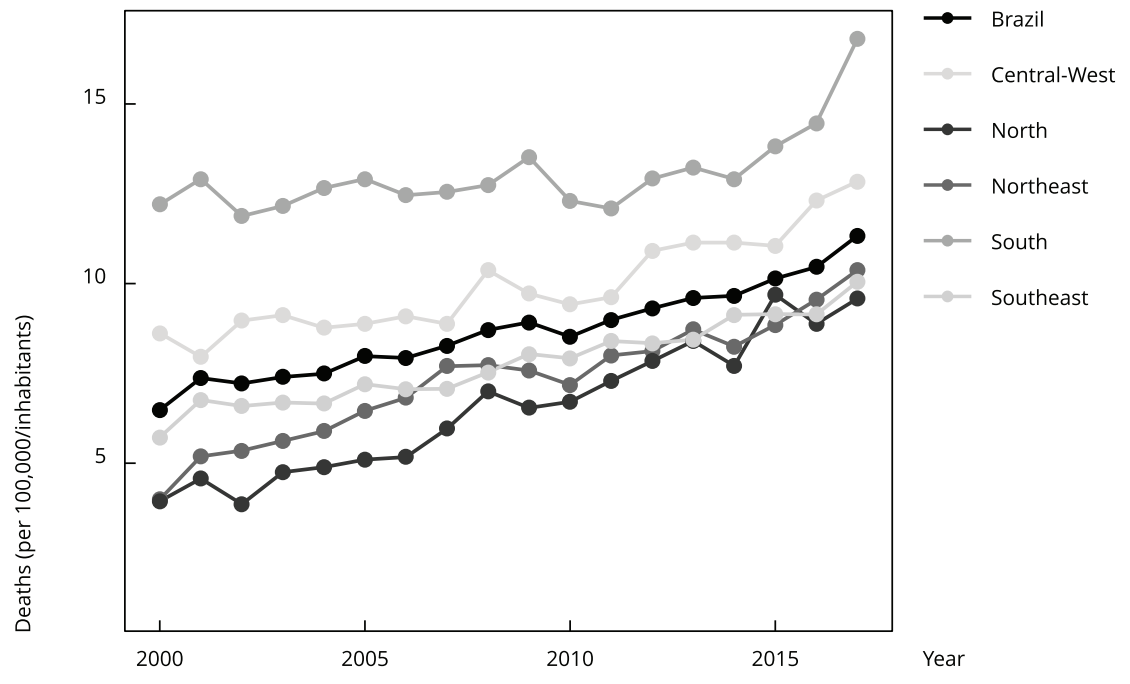


Table 1

Suicide rates in Brazil (per 100,000 inhabitants) standardized by age, sex ratio, and relative percentage change from 2000 to 2017.

\begin{tabular}{|c|c|c|c|c|c|c|c|c|c|}
\hline \multirow[t]{2}{*}{ Year } & \multicolumn{3}{|c|}{ Brazil } & \multicolumn{3}{|c|}{ Central-West } & \multicolumn{3}{|c|}{ Northeast } \\
\hline & Males & Females & $\mathbf{M} / \mathbf{F}$ & Males & Females & $M / F$ & Males & Females & $M / F$ \\
\hline 2000 & 6.48 & 1.61 & 4.0 & 8.62 & 2.34 & 3.7 & 3.99 & 1.11 & 3.6 \\
\hline 2001 & 7.37 & 1.82 & 4.0 & 7.96 & 2.30 & 3.5 & 5.19 & 1.31 & 4.0 \\
\hline 2002 & 7.22 & 1.99 & 3.6 & 8.97 & 2.69 & 3.3 & 5.35 & 1.63 & 3.3 \\
\hline 2003 & 7.40 & 1.86 & 4.0 & 9.12 & 2.19 & 4.2 & 5.62 & 1.64 & 3.4 \\
\hline 2004 & 7.49 & 1.99 & 3.8 & 8.77 & 2.99 & 2.9 & 5.89 & 1.56 & 3.8 \\
\hline 2005 & 7.98 & 2.10 & 3.8 & 8.88 & 2.74 & 3.3 & 6.46 & 1.75 & 3.7 \\
\hline 2006 & 7.93 & 2.05 & 3.9 & 9.09 & 2.40 & 3.8 & 6.82 & 1.71 & 4.0 \\
\hline 2007 & 8.27 & 2.15 & 3.8 & 8.88 & 2.31 & 3.8 & 7.70 & 1.90 & 4.1 \\
\hline 2008 & 8.71 & 2.25 & 3.9 & 10.37 & 2.45 & 4.2 & 7.73 & 2.08 & 3.7 \\
\hline 2009 & 8.92 & 2.18 & 4.1 & 9.72 & 2.62 & 3.7 & 7.58 & 1.88 & 4.0 \\
\hline 2010 & 8.52 & 2.34 & 3.7 & 9.42 & 2.73 & 3.5 & 7.18 & 1.97 & 3.6 \\
\hline 2011 & 8.99 & 2.37 & 3.8 & 9.62 & 2.44 & 3.9 & 8.00 & 1.95 & 4.1 \\
\hline 2012 & 9.31 & 2.55 & 3.7 & 10.91 & 3.02 & 3.6 & 8.12 & 2.08 & 3.9 \\
\hline 2013 & 9.60 & 2.50 & 3.8 & 11.14 & 3.11 & 3.6 & 8.72 & 2.10 & 4.2 \\
\hline 2014 & 9.66 & 2.50 & 3.9 & 11.14 & 2.98 & 3.7 & 8.25 & 2.07 & 4.0 \\
\hline 2015 & 10.14 & 2.69 & 3.8 & 11.05 & 3.06 & 3.6 & 8.85 & 2.31 & 3.8 \\
\hline 2016 & 10.46 & 2.68 & 3.9 & 12.31 & 3.19 & 3.9 & 9.55 & 2.28 & 4.2 \\
\hline 2017 & 11.33 & 2.98 & 3.8 & 12.84 & 3.83 & 3.4 & 10.37 & 2.45 & 4.2 \\
\hline RPC (\%) & 75 & 85 & - & 49 & 64 & - & 160 & 121 & - \\
\hline \multirow[t]{2}{*}{ Year } & \multicolumn{3}{|c|}{ North } & \multicolumn{3}{|c|}{ Southeast } & \multicolumn{3}{|c|}{ South } \\
\hline & Males & Females & $\mathbf{M} / \mathbf{F}$ & Males & Females & M/F & Males & Females & $M / F$ \\
\hline 2000 & 3.94 & 1.11 & 3.5 & 5.72 & 1.39 & 4.1 & 12.20 & 2.92 & 4.2 \\
\hline 2001 & 4.57 & 1.41 & 3.2 & 6.76 & 1.72 & 3.9 & 12.91 & 2.86 & 4.5 \\
\hline 2002 & 3.86 & 1.42 & 2.7 & 6.59 & 1.80 & 3.7 & 11.88 & 2.99 & 4.0 \\
\hline 2003 & 4.75 & 1.24 & 3.8 & 6.69 & 1.67 & 4.0 & 12.16 & 2.78 & 4.4 \\
\hline 2004 & 4.89 & 1.28 & 3.8 & 6.66 & 1.73 & 3.9 & 12.66 & 3.22 & 3.9 \\
\hline 2005 & 5.10 & 1.39 & 3.7 & 7.20 & 1.97 & 3.7 & 12.91 & 2.99 & 4.3 \\
\hline 2006 & 5.17 & 1.44 & 3.6 & 7.06 & 1.91 & 3.7 & 12.46 & 3.09 & 4.0 \\
\hline 2007 & 5.96 & 1.40 & 4.3 & 7.07 & 1.96 & 3.6 & 12.55 & 3.32 & 3.8 \\
\hline 2008 & 7.00 & 1.44 & 4.9 & 7.53 & 2.02 & 3.7 & 12.74 & 3.41 & 3.7 \\
\hline 2009 & 6.54 & 1.49 & 4.4 & 8.04 & 2.11 & 3.8 & 13.52 & 2.91 & 4.7 \\
\hline 2010 & 6.71 & 1.83 & 3.7 & 7.92 & 2.22 & 3.6 & 12.30 & 3.25 & 3.8 \\
\hline 2011 & 7.29 & 2.17 & 3.4 & 8.40 & 2.27 & 3.7 & 12.09 & 3.33 & 3.6 \\
\hline 2012 & 7.84 & 1.70 & 4.6 & 8.34 & 2.45 & 3.4 & 12.92 & 3.79 & 3.4 \\
\hline 2013 & 8.40 & 1.99 & 4.2 & 8.44 & 2.30 & 3.7 & 13.23 & 3.60 & 3.7 \\
\hline 2014 & 7.71 & 2.00 & 3.9 & 9.13 & 2.34 & 3.9 & 12.91 & 3.63 & 3.6 \\
\hline 2015 & 9.69 & 2.40 & 4.0 & 9.15 & 2.48 & 3.7 & 13.82 & 3.80 & 3.6 \\
\hline 2016 & 8.88 & 2.54 & 3.5 & 9.14 & 2.42 & 3.8 & 14.46 & 3.84 & 3.8 \\
\hline 2017 & 9.58 & 2.82 & 3.4 & 10.05 & 2.65 & 3.8 & 16.81 & 4.45 & 3.8 \\
\hline RPC (\%) & 143 & 154 & - & 76 & 91 & - & 38 & 52 & - \\
\hline
\end{tabular}

M/F: male/female ratio; RPC: relative percentage change. 
Table 2

Estimates of trend of suicide rates by gender in Brazil and geographic regions from 2000 to 2017.

\begin{tabular}{|c|c|c|c|c|c|}
\hline Region & Gender & Linear model & p-value * & $\mathbf{r}$ & Trend \\
\hline \multirow[t]{2}{*}{ Brazil } & Male & $\ln (y)=2.15+0.03 x$ & $<0.001$ & 0.96 & $\uparrow$ \\
\hline & Female & $\ln (y)=0.80+0.03 x$ & & 0.94 & \\
\hline \multirow[t]{2}{*}{ Central-West } & Male & $\ln (y)=2.29+0.02 x$ & $<0.001$ & 0.85 & $\uparrow$ \\
\hline & Female & $\ln (y)=1.00+0.02 x$ & & 0.56 & \\
\hline \multirow[t]{2}{*}{ Northeast } & Male & $\ln (y)=1.96+0.04 x$ & $<0.001$ & 0.90 & $\uparrow$ \\
\hline & Female & $\ln (y)=0.61+0.03 x$ & & 0.84 & \\
\hline \multirow[t]{2}{*}{ North } & Male & $\ln (y)=1.84+0.05 x$ & $<0.001$ & 0.95 & $\uparrow$ \\
\hline & Female & $\ln (y)=0.51+0.05 x$ & & 0.85 & \\
\hline \multirow[t]{2}{*}{ Southeast } & Male & $\ln (y)=2.04+0.03 x$ & $<0.001$ & 0.95 & $\uparrow$ \\
\hline & Female & $\ln (y)=0.72+0.03 x$ & & 0.91 & \\
\hline \multirow[t]{2}{*}{ South } & Male & $\ln (y)=2.56+0.01 x$ & 0.002 & 0.46 & $\uparrow$ \\
\hline & Female & $\ln (y)=1.20+0.02 x$ & $<0.001$ & 0.79 & \\
\hline
\end{tabular}

* $p$-value of $\beta$ (beta); p-value of model $<0.001$.

Our research found relevant regional differences in suicide rates, with an unusual similarity between the South and Central-West regions. These regions had the highest rates. On the other hand, in the South and Central-West, the annual percentage changes were lower compared to the other regions of the country. Divergent findings in this study denote a decrease in suicide rates in these regions. A probable reason for the difference in our findings was the estimate of crude rates by other authors 15,16 . However, even with standardization rates, differences between regions were maintained, regardless of population age.

A noteworthy aspect between the South and Central-West is the agribusiness as the main economic activity. The extensive territorial occupation of the South, which had its extensive agricultural production, occurred in the late 19th century and the first half of the 20th century, preceding that of the Central-West, which occurred more intensely only in the 1970s. The main groups of immigrants who settled in southern Brazil were the Germans, Italians, and Slavs, initially in the state of Rio Grande do Sul (1824), and later in Santa Catarina (1851), and Paraná (late 19th century) 17. The Cerrado is a vast tropical savanna and the predominant biome of the Central-West region. This biome, which is known to have infertile land, was inhabited during research on soil fertility, monoculture, and encouraging migration of farmers in the South. Its transformation into agricultural areas accelerated the occupation process and local changes. This occupation process favored the intensification of urbanization and the advance of the agricultural frontier 18.

Historically, the South presents the highest suicide rates, with emphasis on the state of Rio Grande do Sul with the highest suicide rates in Brazil since 1970, when the SIM was created 19,20. The state of Rio Grande do Sul was strongly influenced by German immigrants, with some municipalities dependent on the tobacco plantation. According to Protestant ethics, the suffering of farmers who cultivate tobacco on small family farms, the precarious living conditions of the population involved in agricultural activity, the influence of possible debts, the large tracts of land, the rural exodus, and social isolation may also reflect higher suicide death rates in this location 21,22.

Economic development is also characterized as one of the agents responsible for variations in suicide rates among countries and regions. In 2016, $79 \%$ of suicides occurred in low- and middle-income countries. However, the highest rates were observed in high-income countries 1. In Brazil, the South region has the best economic development indexes and the lowest income inequalities 23 .

Evidence can be found to support a complex relationship between economic conditions and suicide. This relationship is due to the reduction in per capita income, a decrease in the availability of medical and social assistance during an economic crisis. It also occurs due to individual factors, such as the presence of psychological or physical illnesses, which during an economic crisis makes it difficult to find and/or keep better-paid jobs or any type of work 24,25. 


\section{Figure 2}

Variation between trends in suicide rates by gender in Brazil and geographic regions from 2000 to 2017.

2a) Female

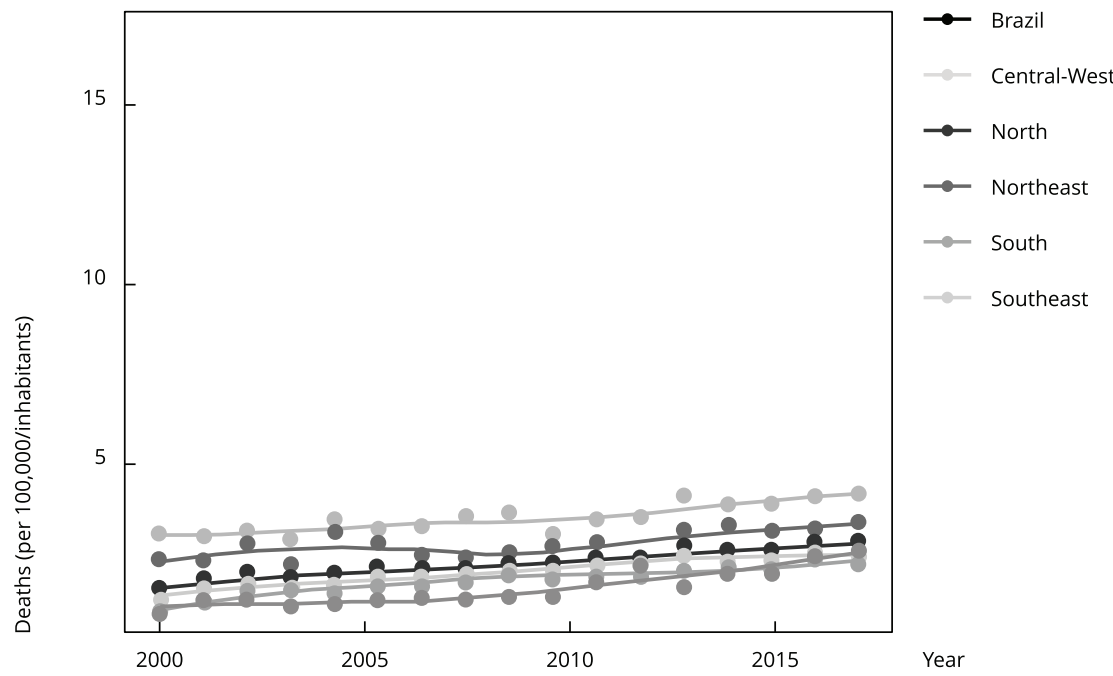

2b) Male

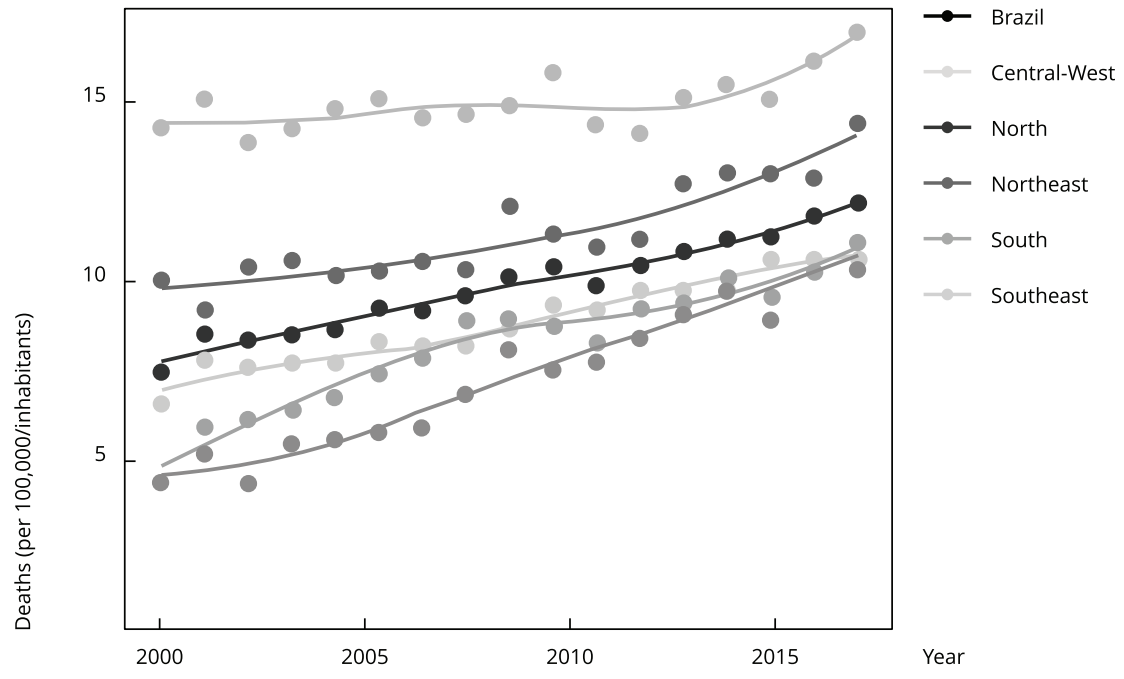

Agricultural workers had higher rates of death from suicide when compared to other occupations. From 2007 to 2015, the rates increased by 23\%, from 16.6 to 20.5 deaths per 100,000 inhabitants 26 . A meta-analysis found higher suicide mortality in agricultural workers compared to other workers, mainly male. These data demonstrate that this association is not restricted to agricultural areas in Brazil 27.

Low income, instability at work, pressure for productivity, limited access to quality education and health services, and debts can be indicated as risk factors for theses workers. Easy access to pesticides is another problem, as their ingestion can be lethal, favoring the consummation of suicide 14,27. 
The higher suicide rates among male rural workers may be explained by the fact that they are the ones who are most exposed to pesticides. This great exposure is due to activities involving pesticides in the rural area, such as the preparation of the spray solution, the spraying with backpack and or tractors, and the washing of equipment 28 .

The risk of pesticides related to suicide goes beyond their use as a tool to consummate it. Studies also suggest pesticides act on the central nervous system or as endocrine disruptors, leading to depression, anxiety, among other mental disorders, or even neurodegenerative diseases, thus contributing to suicide 26,29 .

The Central-West, which has the second-highest suicide rate in the country, also deals with a high rate of suicides among indigenous people, especially in the south of Mato Grosso do Sul. From 2000 to 2008, a total of 410 suicide in the Guarani/Kaiowá ethnic group was registered in Mato Grosso do Sul 30, and 40\% of deaths among indigenous children, aged 10 to 14, within 2010 and 2014 31. In the North, rates are also influenced by indigenous deaths with the Southwest and Northwest regions of the state of Amazonas presenting 27.3\% and 9.1\% of registered deaths, respectively. Suicide for indigenous peoples is seen as a phenomenon associated with conflicts that are strongly linked to the socio-cultural perspectives and life history of their people, which indicate tensions between generations, gender, and family relationship. It is also associated with the demarcation of indigenous lands, the government's attempt to urbanize this population, and different forms of coercion and tensions with agribusiness 31,32 .

Suicide is notable by the condition of gender, as in biological classification, male and female. A study 33 similar to ours conducted in the United States (1975-2016) with young people aged 10 to 19 showing that the difference between the mortality of men and women by suicide is decreasing. In this study, women presented the highest number of deaths. Besides the high rate of female anxiety and depression, women are using more lethal ways, which historically was a characteristic of men. Thus, women are not only thinking more about suicide, but also they are committing suicide 33 . Another characteristic reported most frequently among men is a fearlessness about death, associated with restrictive emotionality. However, recently, a study demonstrated that this element was the one that best explained the risk of suicide among women, a mechanism by which they come to develop 34 .

The Northeast and the North regions presented the highest change on the rates of death by suicide. It is known that these regions have a high degree of inequality, both economically and regarding access to public services. The Northeast region, despite being the third in the ranking of Brazilian Gross Domestic Product 35, still presents the worst social indicators in the country.

Knowing that the quality of information on mortality in the country is variable and strongly related to the socioeconomic conditions of each state, the high increase in the rate of suicide death in these regions possibly reflects improvements in the information systems and data collection by the Federative Units ${ }^{36}$, showing a decrease in differences among regions with recent economic growth.

One of the biggest limitations in working with suicide data is to specify the extent of a possible underreporting, whether because of the taboo surrounding the event or concerning the deaths declared as accidents, drownings, and homicides, classified by Levy 37 as "suicide equivalents". On the other hand, an improvement in reporting can be observed, either due to the implementation of laws or due to the increasing awareness and training of the service network, which may partly justify the progressive increase in reported cases 19 .

This study did not stratify deaths by urban/rural dwelling, considering that the entire population is exposed to pesticides. This exposure can occur either by working and/or living in the countryside, or by consuming products contaminated by pesticides. Another remarkable aspect is the difficulty in establishing the rural and urban borderline, since the applications are made by agricultural airplanes resulting in a greater dispersion of pesticides.

In conclusion, the standardized suicide rates present an increasing trend for Brazil and its geographic regions, for both men and women. The South and Central-West regions had the highest rates compared to the other Brazilian regions, whereas the Northeast and the North regions had the highest growth trend in suicide rates. Differences in death rates from male and female suicide keep evidencing the risk of death by suicide according to gender, emphasizing the need to develop actions aimed at specific audiences. 


\section{Contributors}

D. C. A. Palma contributed to the study design and planning, data collection, data analysis and interpretation, writing and critical review of the manuscript. B. F. A. Oliveira and E. Ignotti contributed with the study design and planning, data analysis and interpretation, writing and critical review of the manuscript. All authors approved the final version of the manuscript.

\section{Additional informations}

ORCID: Danielly Cristina de Andrade Palma (00000002-1128-7874); Beatriz Fátima Alves de Oliveira (0000-0003-0103-3309); Eliane Ignotti (00000002-9743-1856).

\section{Acknowledgments}

The article is part of the doctoral thesis of the D.C.A.P., in the Graduate Program in Environmental Sciences from the State University of Mato Grosso. There was no funding support.

\section{References}

1. World Health Organization. Suicide in the world: global health estimates. https://apps. who.int/iris/handle/10665/326948 (accessed on $15 / \mathrm{Jan} / 2020$ ).

2. Departamento de Informática do SUS. Óbitos por causas externas - Brasil. http://tabnet. datasus.gov.br/cgi/deftohtm.exe?sim/cnv/ ext10uf.def (accessed on 15/Jan/2020).

3. Canetto SS, Sakinofsky I. The gender paradox in suicide. Suicide Life Threat Behav 1998; 28:1-23.

4. Schimelpfening N. Differences in suicide among men and women. https://www. verywellmind.com/gender-differences-insuicide-methods-1067508?print (accessed on 30/Jan/2020).

5. Canetto S. Women and suicidal behavior: a cultural analysis. Am J Orthopsychiatry 2008; 78:259-66.

6. Värnik A, Kõlves K, Allik J, Arensman E, Aromaa E, Audenhove C, et al. Gender issues in suicide rates, trends and methods among youths aged 15-24 in 15 European countries. J Affect Disord 2009; 113:216-26.

7. Botega NJ. Crise suicida: avaliação e manejo. Porto Alegre: Artmed; 2015.

8. Minayo MCS, Cavalcante FG. Suicide in elderly people: a literature review. Rev Saúde Pública 2010; 44:750-7.

9. Kutcher S. Chehil S. Suicide risk management: a manual for health professionals. 2nd Ed. Hoboken: Wiley-Blackwell; 2007.

10. Dhungel B, Sugai MK, Gilmour S. Trends in suicide mortality by method from 1979 to 2016 in Japan. Int J Environ Res Public Health 2019; $16: 1794$.

11. Nunes KVR, Neves SMAS, Ignotti E. Mortality due to diseases of the circulatory system among the elderly populations in Brazilian Amazon: temporal and spatial analysis. Rev Bras Epidemiol 2013; 16:838-48.

12. Silva GA, Noronha CP, Santos MO, Oliveira JFP. Diferenças de gênero na tendência de mortalidade por câncer de pulmão nas macrorregiões brasileiras. Rev Bras Epidemiol 2008; 11:411-9.

13. Antunes JLF, Cardoso MRA. Uso da análise de séries temporais em estudos epidemiológicos. Epidemiol Serv Saúde 2015; 24:565-76.

14. Naghavi M. Global, regional, and national burden of suicide mortality 1990 to 2016: systematic analysis for the Global Burden of Disease Study 2016. BMJ 2019; 364:194.

15. D’Eça Júnior A, Rodrigues LS, Meneses Filho EP, Costa LLN, Rêgo AS. Mortalidade por suicídio na população brasileira, 1996-2015: qual é a tendência predominante? Cad Saúde Colet (Rio J.) 2019; 27:20-4.

16. Machado DB, Santos DN. Suicídio no Brasil, 2001 a 2012. J Bras Psiquiatr 2015; 64:45-54

17. Costa AA, Farias PSC. Formação territorial do Brasil. Campina Grande: EdUEP; 2009. 
18. Silva CM. Between Fenix and Ceres: the great acceleration and the agricultural frontier in the Brazilian Cerrado. Varia Historia 2018; 34:409-44.

19. Centro Estadual de Vigilância em Saúde do Rio Grande do Sul. Boletim de Vigilância Epidemiológica de Suicídio e Tentativa de Suicídio 2018; 1(1). https://www.cevs.rs.gov.br/upload/ arquivos/201809/05162957-boletim-de-vigi lancia-epidemiologica-de-suicidio-n1-2018. pdf.

20. Palma DCA, Santos ES, Ignotti E. Análise dos padrões espaciais e caracterização dos suicídios no Brasil entre 1990 e 2015. Cad Saúde Pública 2020; 36:e00092819.

21. Fraga WS. Determinantes socioeconômicos do suicídio no Brasil e no Rio Grande do Sul no século XXI [Masters Thesis]. São Leopoldo: Universidade do Vale do Rio dos Sinos; 2014.

22. Meneghel SN, Moura R. Suicídio, cultura e trabalho em município de colonização alemã no sul do Brasil. Interface (Botucatu) 2018; 22:1135-46.

23. Instituto Brasileiro de Geografia e Estatítica. Síntese de indicadores sociais: uma análise das condições de vida da população brasileira. Rio de Janeiro: Instituto Brasileiro de Geografia e Estatítica; 2020.

24. Merzagora I, Mugellini G, Amadasi A, Travaini G. Suicide risk and the economic crisis: an exploratory analysis of the case of Milan. PLoS One 2016; 11:e0166244.

25. Mann JJ, Metts AV. The economy and suicide: an interaction of societal and intrapersonal risk factors. Crisis 2017; 38:141-6.

26. Centro Colaborador da Vigilância dos Agravos à Saúde do Trabalhador. Ocupação e suicídio no Brasil, 2007-2015. Boletim Epidemiólogico 2019; (14). http://www.ccvisat.ufba. br/wpcontent/uploads/2019/08/SUICIDIO_ BOLETIM_CCVISATfinalFINAL.pdf.

27. Klingelschmidt J, Milner A, Khireddine-Medouni I, Witt K, Alexopoulos EC, Chastang JF, et al. Suicide among agricultural, forestry, and fishery workers: a systematic literature review and meta-analysis. Scand J Work Environ Health 2018; 44:3-15.
28. Silva DO, Ferreira MJM, Silva SA, Santos MA, Hoffmann-Santos HD, Silva AMC. Exposure to pesticides and acute intoxication in a region of intense agricultural production in Mato Grosso, Brazil, 2013. Epidemiol Serv Saúde 2019; 28:e2018456.

29. Shiva V. The suicide economy of corporate globalisation. http://www.ask-force.org/web/ Cotton/Shiva--Suicide-Economy-2004.pdf (accessed on 03/Feb/2020).

30. Grubits S, Freire HBG, Noriega JAV. Suicídios de jovens Guarani/Kaiowá de Mato Grosso do Sul, Brasil. Psicol Ciênc Prof 2011; 31:504-17.

31. Souza MLP. Mortalidade por suicídio entre crianças indígenas no Brasil. Cad Saúde Pública 2019; 35 Suppl 3:e00019219.

32. Souza MLP. Indigenous narratives about suicide in Alto Rio Negro, Brazil: weaving meanings. Saúde Soc 2016; 25:145-59.

33. Ruch DA, Sheftall AH, Schlagbaum P, Rausch J, Campo JV, Jeffrey A, et al. Trends in suicide among youth aged 10 to 19 years in the United States, 1975 to 2016. JAMA Netw Open 2019; 2:e193886.

34. Fadoir NA, Kuhlman STW, Smith PN. Suicide risk and restricted emotions in women: the diverging effects of masculine gender norms and suicide capability. Arch Suicide Res 2019; 24 Suppl 2:S323-39.

35. Instituto Brasileiro de Geografia e Estatítica. Produto Interno Bruto - PIB. https://www. ibge.gov.br/explica/pib.php (accessed on 15/ $\mathrm{Feb} / 2020$ ).

36. Santos EGO, Barbosa IR. Conglomerados espaciais da mortalidade por suicídio no nordeste do Brasil e sua relação com indicadores socioeconômicos. Cad Saúde Colet (Rio J.) 2017; 25:371-8.

37. Levy M. Introdução ao estudo do suicídio. Boletim de Psiquiatria 1979; 12:1-12. 


\section{Resumo}

O estudo buscou analisar a tendência nas taxas de suicídio padronizadas por gênero de acordo com as macrorregiões brasileiras entre 2000 e 2017. Os dados de mortalidade foram obtidos do Sistema de Informações sobre Mortalidade. Foram utilizados modelos de regressão linear, e testes de Durbin-Watson foram aplicados para verificar a independência dos resíduos, assim como testes de Prais-Winsten para controlar a autocorrelação seriada. As tendências foram classificadas como crescentes, decrescentes e estáveis, com nível de significância de 5\%. A taxa de suicídio padronizada para o sexo masculino aumentou em $75 \%$, de 6,5 para 11,3 óbitos por 100.000 habitantes. Para o sexo feminino, o aumento foi de 85\%, de 1,6 para 3,0 óbitos por 100.000 habitantes. Foi observado um aumento gradual nas taxas de suicídio padronizadas em todas as macrorregiões e em ambos os sexos. O crescimento nas taxas de suicídio no Sul é o dobro para as mulheres, enquanto no Nordeste é maior para os homens. As regiões Sul e Centro -oeste apresentaram as maiores taxas, e a Região Norte apresentou a menor. A tendência das taxas de suicídio padronizadas é linear e cresce significativamente no Brasil e em todas as macrorregiões e em ambos os sexos. As taxas de suicídio em homens e mulheres evidenciam diferenças de risco de acordo com gênero.

Mortalidade; Distribuição por Sexo; Povos Indígenas

\section{Resumen}

El objetivo del estudio fue analizar la tendencia en las tasas estandarizadas de suicidio por género, según las regiones geográficas brasileñas de 2000 a 2017. Los datos de mortalidad fueron recuperados de la base de datos del Sistema de Información sobre Mortalidad brasileño. Se usaron modelos de regresión lineal, y se aplicaron pruebas DurbinWatson para detectar la independencia de los residuos, al igual que el de Prais-Winsten para controlar la autocorrelación en series. Las tendencias fueron clasificadas como crecientes, decrecientes $y$ estables a un nivel de un 5\% significancia. La tasa estandarizada de muertes por suicidio para hombres se incrementó en un 75\%, de 6,5 a 11,3 muertes por 100.000 habitantes. Para las mujeres, el incremento fue de un 85\%, de 1,6 a 3,0 muertes por 100.000 habitantes. El incremento gradual en las tasas de suicidio estandarizado se encontró en todas las regiones para ambos géneros. La magnitud del crecimiento de las tasas de suicidio en el Sur es el doble para mujeres, mientras que para el Noreste es más grande para hombres. Las regiones Sur y Centro-oeste presentaron las tasas más altas, mientras que el Norte la más baja. La tendencia de las tasas estandarizadas de suicidio es lineal $y$ significativamente está aumentando en Brasil y en el total de regiones geográficas para ambos géneros. Las tasas de suicidios de hombres y mujeres mantienen la evidencia de diferencias de riesgo según el género.

Mortalidad; Distribución por Sexo; Pueblos Indígenas
Submitted on $25 / \mathrm{Sep} / 2020$

Final version resubmitted on 20/Jan/2021

Approved on 11/Mar/2021 